\title{
Critical Factors Affecting the Success of Construction Projects in Oman
}

Rami J.A. Hamad*

International College of Engineering and Management, P.O. Box 2511, C.P.O Seeb, P.C. 111, Oman

\section{Bassam A. Tayeh}

Civil Engineering Department, Islamic University of Gaza, P.O. Box 108, Gaza Strip, Palestine

\section{Hamdan A. Al Aisri}

Arabian Industry Projects, Muscat, Oman

*Corresponding author: rami-hamad@hotmail.com; rami@icem.edu.om

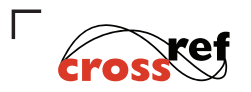

http://dx.doi.org/10.5755/j01.sace.29.2.29269

Construction in Oman is an important sector that contributes greatly to the country's economic growth. Recently, the construction projects in Oman have been delayed which has led to delays in the projects' completion and sometimes to their failure. This study aims to examine the critical factors affecting the success of construction projects in Oman. The extent to which factors related to project parties affect this success was assessed. A quantitative approach based on systematic literature review and questionnaire survey technique was used. The factors were identified and classified into six main categories, namely, time; finance; project designing, planning and scheduling; quality; project progress and development; and environment and nature. The factors are also classified as client-, consultant-, contractor- and externalrelated factors. This study was conducted by distributing questionnaires to people who experienced working in the public and private construction sectors in Oman. Relative importance index method was used for analysis. Results show that quality is the most important amongst the six investigated categories, followed by time; finance; project progress and development; project designing, planning and scheduling; and environment and nature. The client-related factors have the highest impact on the success of construction projects in Oman, followed by consultant-, contractor- and external environment-related factors. The selection of a low bid, rather than accurate and reliable bids, and the quality and experience of the project team and labour are the most significant factors affecting the success of construction projects in Oman. The contractors' administrative corruption, indiscipline and dishonesty and the frequent equipment breakdowns are the two least important factors affecting the success of construction projects. The government should encourage clients to improve their procurement strategies and force the construction companies to implement innovative approaches to project delivery.

Keywords: construction orojects, critical success factors, Oman, project success, relative importance index.

The construction industry is important in the economy of countries (Chan et al., 2004; El-Hallaq \& Tayeh, 2016). The different types of construction projects include buildings, roads and bridges. Oman's construction sector has grown from US\$ 4.9 billion in 2013 to US\$ 5.2 billion in 2014 and is estimated to reach US\$ 5.6 billion in 2015 (Mordor Intelligence, 2017). The Omani government's Ninth Five-Year Development Plan 2016-2020 and the Oman Vision 2020 support the growth in the construction industry by focusing on investments in transport infrastructure (e.g. seaports, railway lines and airports), utility facilities, affordable housing and special economic zones (Global Data, 2017; Building and Construction Authority Singapore, 2017). Under the Ninth Five-Year Development Plan 2016-2020, the government is investing OMR 66.0 billion (US\$ 171.7 billion) until 2020 to devel-

JSACE $2 / 29$

\section{Critical Factors Affecting the Success of Construction Projects in Oman}

Received 2021/06/12

Accepted after revision $2021 / 09 / 14$

\section{Introduction}

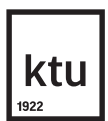

Journal of Sustainable Architecture and Civil Engineering Vol. 2 / No. 29 / 2021 pp. 121-138 DOI 10.5755/j01.sace.29.2.29269 
op the overall infrastructures (Global Data, 2018). In addition, the Omani government aims to attract foreign investments by simplifying the relevant rules and regulations (Mordor Intelligence, 2017).

Project success has no accepted universal definition (Nguye \& Chovichien, 2013). The definition of the success of construction projects varies amongst stakeholders. A project is considered successful if the objectives and expectations are achieved. These objectives and expectations may include different issues, such as technical, financial, educational, social and professional issues (Parfitt \& Sanvido, 1993). In the 1980s, a construction project is considered successful if it is completed within the specified time, budget and required standard of quality in addition to customers' satisfaction (Khosravi \& Afshari, 2011).

The success of a construction project is measured using two categories: small and large viewpoints. The former is measured by time, cost and quality of completion in addition to the completion performance and safety; the latter is assessed by completion time, stakeholders' satisfaction and completion facilities and operation (Lim \& Mohamed, 1999; Abu Aisheh et al., 2021).

However, defining project success has remained unclear for construction professionals; thus, numerous studies on the critical factors affecting the success of construction projects have been conducted in the past years (Chan et al., 2004; Wang \& Huang, 2006; Ramlee et al., 2016; Das \& Ngacho, 2017; Tayeh et al., 2018). Different critical success factors (CSFs), such as safety, quality, time and scheduling, planning, resources, cost and finance, technology, environment, organisation, management, experience, size and type of previous projects, have been defined by several researchers; however, no general agreement has been identified (Belassi \& Tukel, 1996; Ramlee et al., 2016; Alzahrani \& Emsley, 2013; Babu \& Sudhakar, 2015; Maliha et al. 2021).

Chan et al. (2004) classified CSFs into five categories: project-related, project procedures, project management actions, human-related and external environmental factors. Babu (2015) categorised CSFs into 10 main groups: cost, time, quality, productivity, client satisfaction, community, people, health and safety, innovation and learning and environmental factors. Ramlee et al. (2016) summarised the CSFs identified by several researchers to include cost, time, quality, satisfaction, management, safety, technology, organisation, environment and resources. All researchers have agreed that cost, time and quality are important CSFs, whereas $50 \%$ of these researchers have considered management, technology, organisation and satisfaction as important CSFs. Babu and Sudhakar (2015) summarised the most important CSFs within the project life cycle as clarity of project objectives, top management support, efficiency of project manager, efficiency of project team members, detailed plan of the project activities or schedule, effective communication between client and project team members, quality of suppliers and subcontractors, client approvals, monitoring and feedback, suitable technology and communication network and troubleshooting of unexpected crisis and problems.

Kylindri et al. (2012) summarised the specific success dimensions identified by other researchers and found that cost, time, quality, efficiency, performance and technical success factors have been excessively researched. Other factors, such as client satisfaction, safety, team creativity, knowledge and project management process, must be further explored. Al-Tmeemy \& Harun (2011) and Raphael (2016) defined a construction project as successful if it satisfies the specified completion time, total cost, agreed technical specifications of the project and clients' and customers' expectations. These project success measures depend on various factors, such as client, contractor, project team, nature of the project, location and size of the project, technology to be used, contract type and risks involved (Tayeh et al., 2020c).

Abdul-Rahman et al. (2011) identified the possible causes of financial-related problems that contribute to project delays and found that the instability of the contractor's financial background, the unavailability of a project financer and poor cash flow management are major factors contribute to project delays. A well-managed cash flow improves the time performance of the project; con- 
versely, poor cash flow leads to project failure (Abdul-Rahman et al., 2011). Tanzi and Davoodi (1998) and Gillanders (2014) stated that countries with high corruption rate have worse infrastructures than other countries. Tayeh et al. (2018) confirmed that the availability of funding and regularity of payments affect the project's progress and success considerably. Abdul-Rahman et al. (2009) revealed that project delay depends greatly on the client's poor financial management and difficulties in obtaining funding from financers. Homthong and Moungnoi (2016) stated that clients should pay contractors on time to eliminate any delay in the project. Yong and Mustaffa (2012) determined that the client's financial capability and delay of progress payments are the two top client-related factors affecting the construction projects in Malaysia. The contractor's unstable financial situation and inability to perform the work and pay salaries, subcontractors and other expenses affect the project progress negatively and thus lead to project failure (Tayeh et al., 2018).

Oyewobi et al. (2015) stated that variations during construction are time consuming and costly because they increase construction costs and time by $34 \%$ and $29.5 \%$, respectively. These variations also increase project rework and demolition and thus lead to client dissatisfaction and project failure. Frequent equipment breakdowns in construction sites are a common problem that increases the downtime and requires costly repair (Tsado \& Theophilus, 2014).

Chan et al. (2004( and Akanni et al. (2015) reported that the external factors that affect the construction projects include economic, social, political, physical, industrial, legal, cultural and technological factors. Physical factors include climatic condition, weather, natural disaster (e.g. storm, fire and landslide) and unexpected geological conditions. Akanni et al. (2015) found that climatic condition and weather factors are the most important amongst all 29 external factors investigated.

Fong and Choi (2000) stated that the selection process of reliable bids is critical for clients who are seeking for successful projects. This process must not be based on under- or overweighed quality, time and cost criteria. Muhwezi et al. (2014) identified the CSFs related to clients and arranged them in the following order: corruption, poor cash flow, change orders, delay in payments and changes in materials and design. Yong and Mustaffa (2012) reported that the client's excessive variations during construction are the third most important factor that affects the construction projects in Malaysia.

Tayeh et al. (2018) emphasised the importance of the time of the design stage for the successful implementation of projects. Delays during the design stage lead to an overall delay in the work and thus affect the success of the project. Muhwezi et al. (2014) ranked the client's delay in approving design documents as the sixth top client-related factor. Tayeh et al. (2018) observed that the quality and experience of the design team considerably affect the quality and outcomes of the project. Homthong and Moungnoi (2016) determined that the adequate experience of project participants is the second highest critical affecting factor of the success of a project because successful projects require an experienced team to execute the work.

Muhwezi et al. (2014) identified the CSFs related to contractors and arranged them in the following order: dishonesty, inadequate contractor experience, incompetent project manager, inappropriate construction methods and poor site management. Tayeh et al. (2018) stated that the contractor's experience in performing the work is the highest contractor-related affecting factor of construction project success. Yong and Mustaffa (2012) determined that the quality of subcontractors and skills of workers are two top contractor-related factors affecting the success of construction projects in Malaysia. Homthong and Moungnoi (2016) suggested that the availability of skilled and experienced personnel is the second highest human resource-related affecting factor of project operations and progress.

The external factors that affect construction projects are economic, social, political, physical, industrial, legal, cultural and technological factors. Muhwezi et al. (2014) stated that identifying the occurrence of external factors and controlling them are difficult because these factors originate from sources outside the project. Abdul-Rahman et al. (2009) confirmed that financial market instability, 
including inflation of material prices, wages and transportation cost, significantly affects cash flow and leads to project delays. Yong \& Mustaffa (2012) reported that the weather condition factor is the least significant amongst 15 critical factors affecting the success of construction projects in Malaysia. Al Harthi (2005) investigated the effect of variation orders in construction projects in Oman. It was found that costly and time-consuming variation orders appear during construction work and are considered the primary causes of delays and disputes; thus, serious cost impacts and project failure occur. Oyegoke and Al Kiyumi (2017) identified the most important factors affecting the success of mega construction projects in Oman; these factors include selecting the lowest price tendering, rather than the optimal value tender; the financial situation of the main contractor; delay in decision making by clients; poor contractor planning; and cost and time overruns in projects. Al Maktoumi et al. (2020) studied the causes of the delays in construction project in Oman and investigated the effects of such delays. It was found that the delay of construction project completion in Oman was mainly due to client-related factors followed by equipment-related factors, and material related factors. The Client's delay in providing the contractors with the necessary facilities, equipment and sufficient time and the delay in making decisions are the most important factors affecting the construction project progress in Oman. Al Adawi et al. (2020) studied the impact of governmental stakeholders on the progress of projects in Oman. It was found that governmental authorities, through lengthy approval processes, have a crucial effect on delaying the projects completion and hence lead projects to fail. The approval process in Oman is very slow, and the average duration needed for obtaining a single approval from governmental authorities is two to four weeks.

Although Building Information Modeling (BIM) technology is not new to the construction industry, limited research on BIM implementation had been conducted in developing countries, such as GCC countries. Results of the few research studies conducted in KSA, UAE, Turkey and Iraq revealed that most of the construction companies lack knowledge and awareness of Building Information Modeling (BIM) technology. The implementation of BIM technology in construction projects is still at slow rate in the Middle East, especially in Sultanate of Oman (Darwish et al.; 2020; Al-Ashmori et al., 2020; Umar, 2021). Only 20\% of construction companies in Middle East are using BIM in their projects (Gerges et al., 2017). Due to the lack of knowledge and implementation of BIM, the authors did not consider the implementation of BIM technology as a critical factor affecting the success of construction projects in Oman.

Limited works have been conducted to analyse the success of construction projects in Oman and define the critical factors affecting the success of the Omani construction industry (Oyegoke and Al Kiyumi, 2017; Al Maktoumi et al., 2020). There are contradictions in the research results and lack of common agreement amongst researchers on the critical factors affecting the construction projects. It is evident that there is a high need to conduct more research studies to investigate the main factors which lead to success or failure of construction projects in the Sultanate of Oman. Additional studies should be conducted to examine the impact of these factors on the Omani economy for improving the efficiency of construction projects in Oman. In the present study, the critical success factors affecting the success of construction projects in Oman and their impact on the Omani construction sector are investigated using a quantitative approach based on systematic literature review and questionnaire survey technique. The criteria to measure the success of a project are evaluated in terms of time and scheduling, finance and cost, design and planning, quality, progress and productivity, and environment. The extent to which factors related to clients, consultant, contractor and external environment affect the success of construction projects in Oman is also assessed.

Table 1 summarizes the critical factors used in the current study with their references from the previous studies. According to the literature review, the studied factors were classified into four broad categories, namely, client-, consultant-, contractor- and external-related factors. 


\begin{tabular}{|c|c|c|c|}
\hline Category & $\begin{array}{l}\text { Factors } \\
\text { related to }\end{array}$ & Factors & References \\
\hline \multirow{9}{*}{ Time } & Client & Client delay in decision-making & $\begin{array}{l}\text { Oyegoke \& Al Kiyumi, 2017; Das \& } \\
\text { Ngacho, 2017; Al Maktoumi et al.,2020. }\end{array}$ \\
\hline & Client & Client delay in payments & $\begin{array}{l}\text { Abdul-Rahman et al., 2009; Abdul- } \\
\text { Rahman et al., } 2011 .\end{array}$ \\
\hline & Client & $\begin{array}{l}\text { Delay in providing temporary } \\
\text { utilities of water, electricity, and } A / C \\
\text { for construction site }\end{array}$ & $\begin{array}{l}\text { Tayeh et al., 2018; Al Adawi et al., 2020; } \\
\text { Al Maktoumi et al.,2020. }\end{array}$ \\
\hline & $\begin{array}{l}\text { Client/ } \\
\text { Consultant }\end{array}$ & Delay in design (drawings) approval. & $\begin{array}{l}\text { Muhwezi et al., 2014; Tayeh et al., 2016; } \\
\text { Das\& Ngacho, 2017; Oyegoke \& Al } \\
\text { Kiyumi, } 2017 .\end{array}$ \\
\hline & $\begin{array}{l}\text { Client/ } \\
\text { Consultant }\end{array}$ & Delay in approving materials & $\begin{array}{l}\text { Babu, 2015; Tayeh et al., 2016; Das \& } \\
\text { Ngacho, } 2017 .\end{array}$ \\
\hline & Contractor & $\begin{array}{l}\text { Project manager delay in making } \\
\text { and issuing decisions }\end{array}$ & Babu, 2015; Das \& Ngacho, 2017; \\
\hline & Contractor & Unrealistic project timelines & $\begin{array}{l}\text { Oyegoke \& Al Kiyumi, 2017; Das \& } \\
\text { Ngacho, 2017; Al Maktoumi et al.,2020. }\end{array}$ \\
\hline & Contractor & $\begin{array}{l}\text { Shortage and delay in material } \\
\text { supply }\end{array}$ & $\begin{array}{l}\text { Akanni et al., 2015; Al Maktoumi et } \\
\text { al.,2020. }\end{array}$ \\
\hline & External & $\begin{array}{l}\text { Delay in issuing approvals by } \\
\text { authorities }\end{array}$ & Tayeh et al., 2016; Al Adawi et al., 2020. \\
\hline \multirow{6}{*}{ Finance } & Client & Lack of project financing & $\begin{array}{l}\text { Abdul-Rahman et al., 2009; Abdul- } \\
\text { Rahman et al., } 2011 .\end{array}$ \\
\hline & $\begin{array}{l}\text { Client/ } \\
\text { Contractor }\end{array}$ & Poor cash flow (irregular cash flow) & $\begin{array}{l}\text { Abdul-Rahman et al., 2009; Abdul- } \\
\text { Rahman et al., 2011; Albhaisi, } 2016 .\end{array}$ \\
\hline & $\begin{array}{l}\text { Client/ } \\
\text { Contractor/ } \\
\text { Consultant }\end{array}$ & Financial corruption & $\begin{array}{l}\text { Abdul-Rahman et al., 2009; Abdul- } \\
\text { Rahman et al., 2011; Gillanders, 2014; } \\
\text { Albhaisi, } 2016 .\end{array}$ \\
\hline & Contractor & $\begin{array}{l}\text { Contractor's unstable financial } \\
\text { situation }\end{array}$ & $\begin{array}{l}\text { Abdul-Rahman et al., 2009; Abdul- } \\
\text { Rahman et al., 2011; Alzahrani \& } \\
\text { Emsley, 2013; Tayeh et al., } 2016 .\end{array}$ \\
\hline & External & Poor economic conditions & $\begin{array}{l}\text { Abdul-Rahman et al., 2009; Abdul- } \\
\text { Rahman et al., 2011. }\end{array}$ \\
\hline & External & $\begin{array}{l}\text { Inflation (material prices, labor, and } \\
\text { transportation costs) }\end{array}$ & $\begin{array}{l}\text { Abdul-Rahman et al., 2009; Abdul- } \\
\text { Rahman et al., 2011; Akanni et al., } 2015 .\end{array}$ \\
\hline \multirow{5}{*}{$\begin{array}{l}\text { Project } \\
\text { Designing, } \\
\text { Planning and } \\
\text { Scheduling }\end{array}$} & Client & $\begin{array}{l}\text { Inadequate information provided by } \\
\text { a client during feasibility studies }\end{array}$ & $\begin{array}{l}\text { Chan et al., 2004; Babu \& Sudhakar, } \\
\text { 2015; Das \& Ngacho, 2017; Tayeh et al., } \\
\text { 2017; Al Maktoumi et al.,2020. }\end{array}$ \\
\hline & Consultant & $\begin{array}{l}\text { Misunderstanding of owner } \\
\text { requirement and project objectives }\end{array}$ & $\begin{array}{l}\text { Muhwezi et al., 2014; Homthong \& } \\
\text { Moungnoi, 2016; Das \& Ngacho, 2017; } \\
\text { Tayeh et al., 2018; Tayeh et al., } 2019 .\end{array}$ \\
\hline & Consultant & $\begin{array}{l}\text { Insufficient data collection and } \\
\text { survey prior to design }\end{array}$ & $\begin{array}{l}\text { Muhwezi et al., 2014; Babu \& Sudhakar, } \\
\text { 2015; Das \& Ngacho, 2017; Tayeh et al., } \\
\text { 2018. }\end{array}$ \\
\hline & Consultant & $\begin{array}{l}\text { Errors in design and failure to } \\
\text { satisfy design objectives }\end{array}$ & $\begin{array}{l}\text { Muhwezi et al., 2014; Babu \& Sudhakar, } \\
\text { 2015; Babu, } 2015 .\end{array}$ \\
\hline & Contractor & $\begin{array}{l}\text { Ineffective project planning and } \\
\text { schedule }\end{array}$ & $\begin{array}{l}\text { Al-Tmeemy \& Harun, 2011; Das \& } \\
\text { Ngacho, 2017; Oyegoke \& Al Kiyumi, } \\
2017 .\end{array}$ \\
\hline
\end{tabular}

Table 1

Factors used in the questionnaire 


\begin{tabular}{|c|c|c|c|}
\hline Category & $\begin{array}{l}\text { Factors } \\
\text { related to }\end{array}$ & Factors & References \\
\hline \multirow{6}{*}{ Quality } & Client & $\begin{array}{l}\text { Selection of a low bid, rather than } \\
\text { an accurate and reliable bid }\end{array}$ & $\begin{array}{l}\text { Fong \& Choi, 2000; Chan et al., 2004; } \\
\text { Meland et al., 2011; Oyegoke \& Al } \\
\text { Kiyumi, 2017. }\end{array}$ \\
\hline & $\begin{array}{l}\text { Contractor/ } \\
\text { Consultant }\end{array}$ & $\begin{array}{l}\text { Unqualified/inadequate } \\
\text { experienced labor and team }\end{array}$ & $\begin{array}{l}\text { Muhwezi et al., 2014; Babu, 2015; Das \& } \\
\text { Ngacho, 2017; Al Maktoumi et al.,2020. }\end{array}$ \\
\hline & Contractor & Incompetent project manager & $\begin{array}{l}\text { Babu \& Sudhakar, 2015; Babu, 2015; } \\
\text { Tayeh et al., 2020a. }\end{array}$ \\
\hline & Contractor & Unqualified suppliers & $\begin{array}{l}\text { Al Maktoumi et al., 2020; Alzahrani \& } \\
\text { Emsley, } 2013 .\end{array}$ \\
\hline & Contractor & Unqualified sub-contractors & $\begin{array}{l}\text { Das \& Ngacho, 2017; Al Maktoumi et } \\
\text { al., } 2020 .\end{array}$ \\
\hline & Contractor & Poor quality of materials & $\begin{array}{l}\text { Homthong \& Moungnoi, 2016; Al } \\
\text { Maktoumi et al., 2020; Tayeh et al., } \\
\text { 2020b. }\end{array}$ \\
\hline \multirow{12}{*}{$\begin{array}{l}\text { Project } \\
\text { Progress and } \\
\text { Development }\end{array}$} & Client & $\begin{array}{l}\text { Design changes and variations } \\
\text { during construction work }\end{array}$ & $\begin{array}{l}\text { Al Harty, 2005; Oyewobi et al.,2016; Das } \\
\text { \& Ngacho, 2017; Al Maktoumi et al., } \\
2020 .\end{array}$ \\
\hline & Client & $\begin{array}{l}\text { Lack of incentives for contractors to } \\
\text { follow project schedule }\end{array}$ & Chan et al., 2004; Chen et al., 2021. \\
\hline & $\begin{array}{l}\text { Client/ } \\
\text { Consultant/ } \\
\text { Contractor }\end{array}$ & $\begin{array}{l}\text { Poor communication and } \\
\text { coordination with other project } \\
\text { parties }\end{array}$ & $\begin{array}{l}\text { Chan et al., 2004; Wang \& Huang, 2206; } \\
\text { Babu \& Sudhakar, 2015; Homthong \& } \\
\text { Moungnoi, 2016; Das \& Ngacho, 2017; } \\
\text { Nguye \& Chovichien, 2013; Tayeh et al., } \\
\text { 2018; Malik et al.,2021. }\end{array}$ \\
\hline & Consultant & $\begin{array}{l}\text { Inadequate project management } \\
\text { assistance }\end{array}$ & $\begin{array}{l}\text { Al-Tmeemy \& Harun, 2011; Babu \& } \\
\text { Sudhakar, } 2015 .\end{array}$ \\
\hline & Consultant & $\begin{array}{l}\text { Poor supervision of consultant to } \\
\text { contractor activities }\end{array}$ & $\begin{array}{l}\text { Chan et al., 2004; Homthong \& } \\
\text { Moungnoi, } 2016 .\end{array}$ \\
\hline & Contractor & $\begin{array}{l}\text { Poor site management and } \\
\text { supervision by a project manager }\end{array}$ & $\begin{array}{l}\text { Belassi \& Tukel, 1996; Homthong \& } \\
\text { Moungnoi, } 2016 .\end{array}$ \\
\hline & Contractor & $\begin{array}{l}\text { Poor risk management and } \\
\text { inappropriate handling of } \\
\text { unexpected problems and crises }\end{array}$ & $\begin{array}{l}\text { Alzahrani \& Emsley, 2013; Homthong \& } \\
\text { Moungnoi, } 2016 .\end{array}$ \\
\hline & Contractor & $\begin{array}{l}\text { Inadequate implementation of } \\
\text { health and safety procedures }\end{array}$ & $\begin{array}{l}\text { Chan et al., 2004; Homthong \& } \\
\text { Moungnoi, 2016; Tayeh et al., 2018; } \\
\text { Mahfuth et al.,2019. }\end{array}$ \\
\hline & Contractor & Lack of materials & $\begin{array}{l}\text { Akanni et al., 2015; Al Maktoumi et } \\
\text { al.,2020. }\end{array}$ \\
\hline & Contractor & Frequent equipment breakdowns & $\begin{array}{l}\text { Tsado \& Theophilus, 2014; Homthong } \\
\text { \& Moungnoi, 2016; Al Maktoumi et } \\
\text { al.,2020. }\end{array}$ \\
\hline & Contractor & $\begin{array}{l}\text { Administrative corruption, } \\
\text { indiscipline, and dishonesty }\end{array}$ & $\begin{array}{l}\text { Alzahrani \& Emsley, 2013; Gillanders, } \\
\text { 2014; Muhwezi et al., } 2014 .\end{array}$ \\
\hline & Contractor & Shortage of labor and equipment & $\begin{array}{l}\text { Belassi \& Tukel, 1996; Akanni et al., } \\
\text { 2015; Al Maktoumi et al., } 2020 .\end{array}$ \\
\hline Environment & External & $\begin{array}{l}\text { Emergence of natural factors, such } \\
\text { as rainstorms, windstorms, and } \\
\text { floods }\end{array}$ & $\begin{array}{l}\text { Akanni et al., 2015; Das \& Ngacho, } \\
\text { 2017; Tayeh et al., } 2018 .\end{array}$ \\
\hline
\end{tabular}




\section{Date Collection Method}

Quantitative research is usually conducted to quantify a problem by creating numerical data or data that can be converted into applicable statistics (Fellows \& Liu, 1997). In this study, a quantitative approach was used as the main method to obtain appropriate and accurate data. Data collection was conducted by distributing questionnaires to people who have a long work experience in the public and private construction sectors in Oman. Data analysis was conducted using relative importance index method.

These respondents were clients, sponsors, project managers, project team members, contractors and people involved in the project implementation. The questions in the questionnaires were formulated based on the data collected from the literature review and interviews conducted with key people in the construction industry. The critical factors used in designing the questionnaire are summarized in Table 1. The studied factors are classified into four broad categories, namely, client-, consultant-, contractor- and external-related factors.

\section{Research Location and Duration}

This study was conducted in Muscat Governorate during two different periods from October 2017 to March 2018 and from January to April 2021.

\section{Sample Size and Population}

One Hundred Fifty questionnaires were distributed. The total number of the collected questionnaires was 77 , which represents $51 \%$ of the total distributed copies. The number and classification of the respondents were 17 client representatives, 23 contracting engineers, 10 project managers, 23 architects and consulting engineers and 4 site supervisors. The respondents had $5-28$ years of experience in the construction industry.

\section{Questionnaire Design}

The questionnaires were designed on the basis of the objectives of the study, literature review outcomes and personal interviews with experts in the Omani construction sector. The questionnaire has 43 questions, which were divided into two main groups, namely, general and specific questions. General questions include multiple-choice questions about personal and organisational information (four items). Subject-related specific questions include five-point Likert scale questions, which measure the level of agreement of respondents on the proposed factors of project success. The levels of agreement used were presented as follows: 1 = Strongly disagree, 2 = Disagree, $3=$ Neither agree nor disagree, $4=$ Agree and $5=$ Strongly agree. A total of 39 factors affecting the success of construction projects were identified and divided into the following main categories.

- Time

Finance

- Project designing, planning and scheduling
_ Quality

_ Project progress and development

_. Environment and nature

\section{Data analysis}

The contribution and ranking of each of the factors as perceived by the respondents are analysed using relative importance index (RII) method (Muhwezi et al., 2014). Equation (1) is used to calculate the RII, and the results are summarised in Table 2.

$$
R I I=\frac{\sum W}{A \cdot N},
$$

where $W$ - weight given to each factor by the respondents and ranges from 1 to 5

A - highest response weight (5)

$\mathrm{N}$ - total number of respondents 
Table 2

RII, Mean Score and Rank for all Factors used in the Study

\begin{tabular}{|c|c|c|c|c|c|c|}
\hline Category & $\begin{array}{l}\text { Factors } \\
\text { related to }\end{array}$ & Factors & Rank & $\begin{array}{l}\text { Mean } \\
\text { Score }\end{array}$ & $\begin{array}{l}\text { Std. } \\
\text { Dev. }\end{array}$ & RII \\
\hline \multirow{10}{*}{ Time } & External & Delay in issuing approvals by authorities. & 1 & 3.51 & 1.02 & 0.702 \\
\hline & $\begin{array}{l}\text { Client } \\
\text { Consultant }\end{array}$ & Delay in design (drawings) approval & 2 & 3.41 & 1.19 & 0.682 \\
\hline & Client & Client delay in payments. & 3 & 3.38 & 0.98 & 0.676 \\
\hline & Client & Client delay in decision-making. & 4 & 3.35 & 0.98 & 0.670 \\
\hline & $\begin{array}{l}\text { Client } \\
\text { Consultant }\end{array}$ & Delay in approving materials. & 5 & 3.32 & 1.23 & 0.664 \\
\hline & Contractor & Delay and shortage in material supply. & 6 & 3.32 & 1.08 & 0.664 \\
\hline & Contractor & Unrealistic project timelines. & 7 & 3.24 & 1.14 & 0.648 \\
\hline & Client & $\begin{array}{l}\text { Delay in providing temporary utilities of water, } \\
\text { electricity, and A/C for construction site. }\end{array}$ & 8 & 3.11 & 1.26 & 0.622 \\
\hline & Contractor & $\begin{array}{l}\text { Project manager delay in making and issuing } \\
\text { decisions. }\end{array}$ & 9 & 3.05 & 1.08 & 0.610 \\
\hline & \multicolumn{3}{|c|}{ Overall } & 3.30 & & 0.660 \\
\hline \multirow{7}{*}{ Finance } & Contractor & Contractor's unstable financial situation. & 1 & 3.41 & 1.21 & 0.682 \\
\hline & Client & Lack of project financing. & 2 & 3.35 & 1.32 & 0.670 \\
\hline & External & $\begin{array}{l}\text { Inflation (material prices, labor, and transportation } \\
\text { costs). }\end{array}$ & 3 & 3.19 & 1.17 & 0.638 \\
\hline & $\begin{array}{l}\text { Client } \\
\text { Contractor } \\
\text { Consultant }\end{array}$ & Financial corruption. & 4 & 3.00 & 1.53 & 0.600 \\
\hline & External & Poor economic conditions. & 5 & 2.95 & 1.29 & 0.590 \\
\hline & $\begin{array}{l}\text { Client } \\
\text { Contractor }\end{array}$ & Poor cash flow (irregular cash flow). & 6 & 2.95 & 1.10 & 0.590 \\
\hline & \multicolumn{3}{|c|}{ Overall } & 3.14 & & 0.628 \\
\hline \multirow{6}{*}{$\begin{array}{l}\text { Project } \\
\text { Designing, } \\
\text { Planning } \\
\text { and } \\
\text { Scheduling }\end{array}$} & Client & $\begin{array}{l}\text { Inadequate information provided by a client during } \\
\text { feasibility studies. }\end{array}$ & 1 & 3.19 & 1.22 & 0.638 \\
\hline & Consultant & $\begin{array}{l}\text { Errors in design and failure to satisfy design } \\
\text { objectives. }\end{array}$ & 2 & 3.08 & 1.19 & 0.616 \\
\hline & Consultant & Insufficient data collection and survey prior to design. & 3 & 3.00 & 1.33 & 0.600 \\
\hline & Contractor & Ineffective project planning and schedule. & 4 & 2.92 & 1.38 & 0.584 \\
\hline & Consultant & $\begin{array}{l}\text { Misunderstanding of owner requirement and project } \\
\text { objectives. }\end{array}$ & 5 & 2.84 & 1.30 & 0.568 \\
\hline & \multicolumn{3}{|c|}{ Overall } & 3.01 & & 0.601 \\
\hline \multirow{7}{*}{ Quality } & Client & $\begin{array}{l}\text { Selection of a low bid, rather than an accurate and } \\
\text { reliable bid }\end{array}$ & 1 & 3.65 & 1.46 & 0.730 \\
\hline & $\begin{array}{l}\text { Contractor } \\
\text { consultant }\end{array}$ & $\begin{array}{l}\text { Unqualified/ inadequate experienced labor and } \\
\text { team }\end{array}$ & 2 & 3.65 & 1.25 & 0.730 \\
\hline & Contractor & Unqualified sub-contractors & 3 & 3.54 & 1.02 & 0.708 \\
\hline & Contractor & Unqualified suppliers & 4 & 3.46 & 1.30 & 0.692 \\
\hline & Contractor & Poor quality of materials & 5 & 3.19 & 1.13 & 0.638 \\
\hline & Contractor & Incompetent project manager & 6 & 2.86 & 1.25 & 0.572 \\
\hline & \multicolumn{3}{|c|}{ Overall } & 3.39 & & 0.678 \\
\hline
\end{tabular}




\begin{tabular}{|c|c|c|c|c|c|c|}
\hline Category & $\begin{array}{l}\text { Factors } \\
\text { related to }\end{array}$ & Factors & Rank & $\begin{array}{l}\text { Mean } \\
\text { Score }\end{array}$ & $\begin{array}{l}\text { Std. } \\
\text { Dev. }\end{array}$ & RII \\
\hline \multirow{13}{*}{$\begin{array}{l}\text { Project } \\
\text { Progress and } \\
\text { Development }\end{array}$} & Client & $\begin{array}{l}\text { Design changes and variations during construction } \\
\text { work. }\end{array}$ & 1 & 3.54 & 1.14 & 0.708 \\
\hline & Consultant & Inadequate project management assistance & 2 & 3.30 & 1.18 & 0.660 \\
\hline & Client & $\begin{array}{l}\text { Lack of incentives for contractors to follow project } \\
\text { schedule }\end{array}$ & 3 & 3.22 & 1.20 & 0.644 \\
\hline & Contractor & $\begin{array}{l}\text { Poor site management and supervision by a project } \\
\text { manager. }\end{array}$ & 4 & 3.16 & 1.14 & 0.632 \\
\hline & Contractor & Lack of materials & 5 & 3.11 & 1.20 & 0.622 \\
\hline & Contractor & Shortage of labor and equipment & 6 & 3.08 & 1.04 & 0.616 \\
\hline & $\begin{array}{l}\text { Client } \\
\text { Consultant } \\
\text { Contractor }\end{array}$ & $\begin{array}{l}\text { Poor communication and coordination with other } \\
\text { project parties. }\end{array}$ & 7 & 3.08 & 1.26 & 0.616 \\
\hline & Consultant & Poor supervision of consultant to contractor activities & 8 & 3.05 & 1.10 & 0.610 \\
\hline & Contractor & $\begin{array}{l}\text { Poor risk management and inappropriate handling } \\
\text { of unexpected problems and crises }\end{array}$ & 9 & 3.05 & 1.13 & 0.610 \\
\hline & Contractor & $\begin{array}{l}\text { Inadequate implementation of health and safety } \\
\text { procedures }\end{array}$ & 10 & 2.95 & 1.18 & 0.590 \\
\hline & Contractor & Administrative corruption, indiscipline, and dishonesty & 11 & 2.73 & 1.22 & 0.546 \\
\hline & Contractor & Frequent equipment breakdowns & 12 & 2.62 & 1.01 & 0.524 \\
\hline & \multicolumn{3}{|c|}{ Overall } & 3.08 & & 0.615 \\
\hline Environment & External & $\begin{array}{l}\text { Emergence of natural factors, such as rainstorms, } \\
\text { windstorms, and floods }\end{array}$ & 1 & 2.78 & 1.18 & 0.556 \\
\hline
\end{tabular}

\section{Study Limitation}

The first limitation of the current study is the relatively small number of respondents. Although there are significant conclusions made based on the responses obtained from the survey respondents, the findings may not accurately reflect the opinion of the entire professionals in the Omani construction sector. Secondly, this study was conducted in the Muscat Governorate and all questionnaires were distributed amongst professionals who are working in Muscat. The limitations identified by this study suggest that further studies should be conducted targeting the construction professionals who are working in cities other than Muscat to increase the sample size and maximise the accuracy of the current results.

\section{General Information of the Respondents}

The respondent sample includes 17 client representatives, 27 contracting engineers and supervisors, 10 projects managers and 23 consulting architects/engineers. A total of $58 \%$ of the respondents work in various government construction projects, whereas $42 \%$ of them work in private construction projects. A total of 27, 23, 19, 5 and 3 of the respondents have total years of experience of $1-5,6-10,11-15,16-20$ and above 20 years, respectively. Therefore, the respondents are adequately qualified to answer the distributed set of questions.

\section{Critical Factors affecting the Success of Construction Projects in Oman}

Table 2 lists the Rlls for all factors used in this study. These factors, which affect the success of construction projects in Oman, are classified into six main categories, namely, time; finance; project designing, planning and scheduling; quality; project progress and development; and environment and nature. The overall RIl of the main categories is presented in Table 3. 


\begin{tabular}{cl|c|c}
\multirow{2}{*}{$\begin{array}{c}\text { Table 3 } \\
\text { Overall Mean RIls } \\
\text { of Main Categories }\end{array}$} & Quality & Rategory & Rank \\
\cline { 2 - 4 } & Time & 0.678 & 1 \\
\cline { 2 - 4 } & Finance & 0.660 & 2 \\
\cline { 2 - 4 } & Project Progress and Development & 0.628 & 3 \\
\hline & Project Designing, Planning and Scheduling & 0.601 & 4 \\
\hline & Environment & 0.556 & 6 \\
\hline
\end{tabular}

Table 3 shows that quality factors are the most important factors amongst the six investigated categories, whereas the environmental category is the least. The mean RII of quality factors category is 0.678 , followed by time; finance; project progress and development; project designing, planning and scheduling; and environmental factors with the Rlls of $0.66,0.628,0.615,0.601$

and 0.556, respectively. This finding is consistent with the findings of Ramlee et al. (2016) in which cost, time and quality were found the three main important CSFs of construction projects, whereas safety, environment and resources were the least important ones.

\section{Quality Factors}

The results, presented in Table 2, show that selecting a low bid, rather than an accurate and reliable bid, is a significant quality-related affecting factor of the success of construction projects in Oman with an RII of 0.73 . Similarly, the quality of project team and experience of labour significantly affect the success of construction projects in Oman, followed by the quality of subcontractors, suppliers and materials with Rlls of $0.73,0.708,0.692$ and 0.638 , correspondingly. Although the quality and efficiency of the project manager are crucial, they rank the least quality-related factor that affects the success of construction projects in Oman with an RII value of 0.572 . Values exceeding 0.5 are considered of large effects.

These finding are consistent with the previous studies in which the selection criteria and tendering evaluation are considered important success factors of construction projects (Fong \& Choi, 2000; Chan et al., 2004; Meland et al., 2011; Oyegoke \& Al Kiyumi, 2017). Meland et al. (2011) argued that a high focus on price in the tendering evaluation of construction projects deteriorate the project outcome in terms of cost and quality.

\section{Time Factors}

Table 2 shows that the delay in obtaining approvals from government authorities and the delay of clients and consultants in approving the drawings are two major time-related factors affecting the success of Omani construction projects with Rlls of 0.702 and 0.682 , respectively. These findings are consistent with the results obtained from previous studies in which the delays in obtaining the approvals of local authorities are considered a dominant affecting factor of the success of any development (Ratcliffe \& Stubbs, 2003; Evans, 2004; Al Adawi et al., 2020).

Although the delay in obtaining the approval of project management on critical issues, such as scope, resources and major tasks, is considered a significant factor that can derail a project from the beginning. The results show that the delay in obtaining internal approvals of the project manager is the least important time-related affecting factor of the overall success of the construction projects in Oman with an RII of 0.610 .

\section{Finance Factors}

The results of the present study, as summarised in Table 2, confirm that the instability of the contractor's financial background and the unavailability of a project financer are the two major financial-related factors affecting the success of construction projects in Oman. The two factors have RIls of 0.682 and 0.670 , which imply high significance. These findings are consistent with the results obtained by Abdul-Rahman et al. (2011) who found that the client's insufficient financial resources and the contractor's unstable financial background are the most significant factors that lead to project delay. 
Although the client and contractor's poor cash flow management is a significant reason for project failure, the results show that this factor with an RII of 0.59 is the least important financial-related affecting factor of the success of construction projects in Oman. This factor ranks the least, but its RIl exceeds 0.5 indicating that this factor is as important as the other factors.

\section{Project Progress and Development Factors}

The results of the present study, as summarised in Table 2, show that the design changes and variations during the construction work exhibit a significant negative impact on the project performance and progress, thereby leading to project failure. This factor has an RII of 0.708 .

This finding is consistent with the findings of Oyewobi et al. (2015) who found that variations during construction are time consuming and costly because they increase construction costs and time by $34 \%$ and $29.5 \%$, respectively.

The consultant shares advice, makes recommendations, solves problems and determines the optimal actions to be undertaken during the project duration to improve the project progress. Poor project management assistance provided by the consultant to the project team leads to a disastrous result in the construction projects. This finding is confirmed by the survey results, where it ranks as the second significant factor that leads to construction project failure in Oman with an RIl of 0.66 .

However, the failure of equipment has subsequent impacts on the progress of the work and delivery of the services, this factor ranks the least project progress and development-related factors affecting the success of construction projects in Oman with an RII of 0.524 .

\section{Project Designing, Planning and Scheduling Factors}

The study results, as presented in Table 2, indicate that inadequate information provided by the client during feasibility studies ranks the major factor related to project designing, planning and scheduling with an RII of 0.638 . The pre-construction information provided by the client to the contractors and designers during tendering, designing and planning stages must be clear, understandable, concise and in a convenient form to enable distinct performance of duties. Consultants' errors in design and failure to satisfy the design objectives rank the second factor with an RII of 0.616 , whereas consultants' misunderstanding of the client's requirements and the project objectives is the least important with an RII of 0.568 .

\section{Environment and Nature Factors}

In the present study, the effect of bad weather conditions, such as rainstorms, winds, tornadoes and floods, is one of the least factors affecting the success of construction projects in Oman. This factor has an RII of 0.556 , which exceeds 0.5 and thus indicates that it is as important as the remaining factors. This finding contradicts with the results of previous research studies. Chan et al. (2004( and Akanni et al. (2015) stated that climatic condition and weather factors rank as the second most important amongst all external factors investigated in their studies.

\section{Contribution of the Project Team in the Success of Construction Projects in Oman}

The results presented in Tables 4-6 indicate that the factors related to the client have the highest impact on the success of construction projects in Oman, followed by those related to the consultant and contractor with overall Rlls of $0.655,0.635$ and 0.624 , respectively.

\section{Client-Related Factors affecting the Success of Construction Projects in Oman}

The summary of results in Table 4 indicates that quality, time and project progress are the most important categories related to the client's role in the success of construction projects. The results of the current study are similar to the findings obtained in previous studies (Fellows \& liu, 1997; Fong \& Choi, 2000; Yong \& Mustaffa, 2012, Al Maktoumi et al., 2020). Specifically, the respondents agree that the client's selection of a low bid, rather than an accurate and reliable bid, is the key 


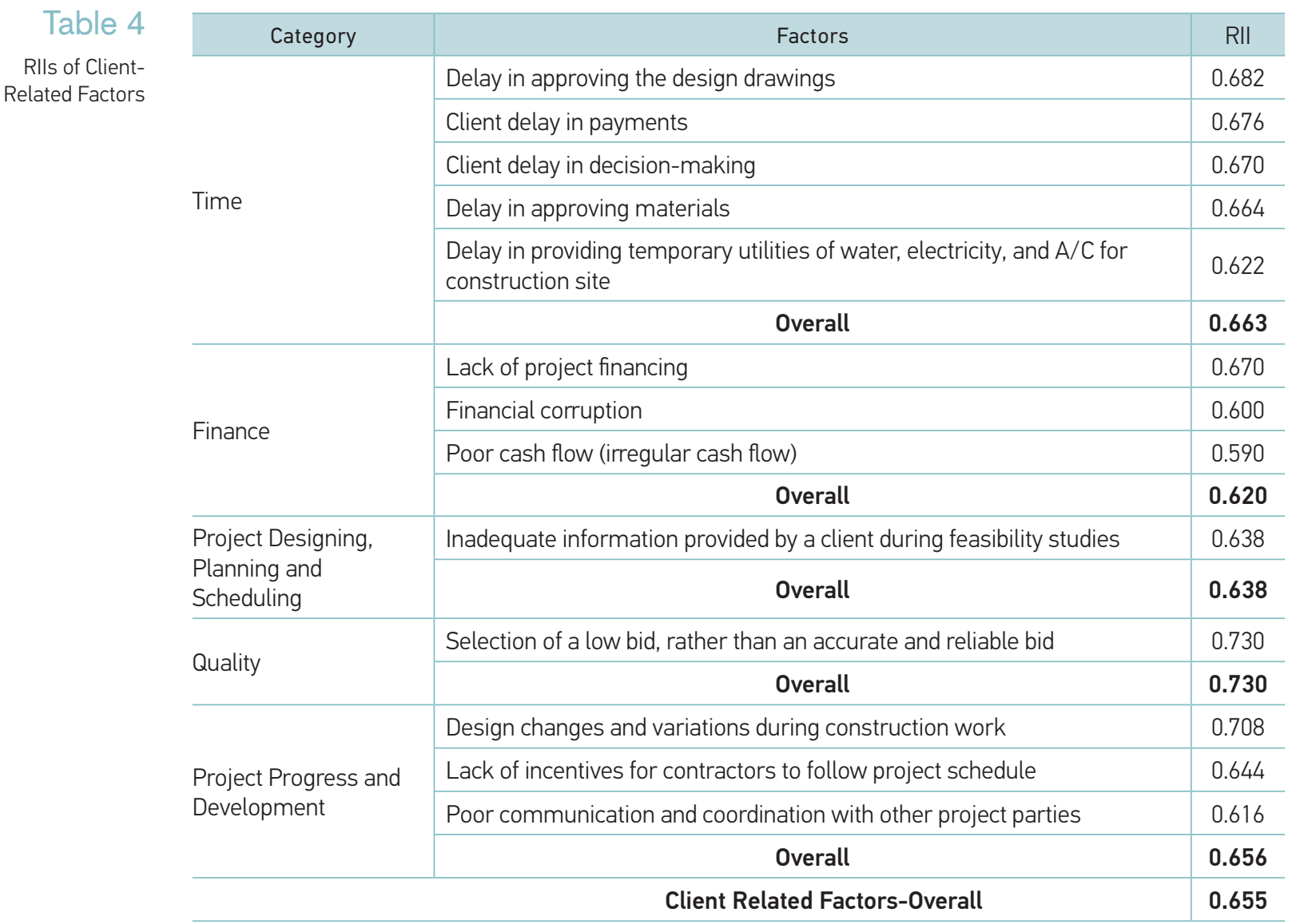

client-related affecting factor of the construction projects in Oman with an RII of 0.73 , followed by the client's design change and variation orders during a construction work with an RII of 0.708.

Delays during the design stage lead to an overall delay in the work and thus affect the success of the project. The findings of previous research studies carried out by Muhwezi et al. (2014) and Tayeh et al. (2018) are supported by the current results, which show that the client's delay in design approvals is the third highest client-related factor with an RII of 0. 682 .

The availability of funding, regularity of payments, and the client's poor financial management affect the project's progress and success considerably (Abdul-Rahman et al., 2009; Yong and Mustaffa, 2012; Homthong and Moungnoi, 2016; Tayeh et al., 2018). These findings are consistent with the current results, where a lack of project financing and the client's delay in payments are highly important with Rlls of 0.67 and 0.676 , respectively.

\section{Consultant-Related Factors affecting the Success of Construction Projects in Oman}

Similar to client-related factors, quality- and time-related factors are the most important categories related to the consultant's role in construction project success. The respondents of the current survey agree that the quality and the experience of the consultant team and designers are crucial success factors with an RII of 0.73 , as summarised in Table 5 . This finding matches with the findings of previous studies conducted by Homthong and Moungnoi (2016) and Tayeh et al. (2018), where the quality, experience of the design team and experience of project participants considerably affect the quality and outcomes of the project because successful projects require an experienced team to execute the work.

The current results indicate that the consultant's delays in approving the design drawings and materials significantly affect the overall delay of the construction project and thus the project success. 
The Rlls of these factors are 0.682 and 0.664 , respectively. The design activity is broadly conducted by consultants to translate the client's goals and concepts into workable construction systems. Muhwezi et al. (2014) analysed the consultant's misunderstanding of the client's requirement; this factor is significant with an RII of 0.742. In the present study, the consultant's misunderstanding of the client's requirement and project objectives has been found as the least important consultant-related affecting factor of the success of construction projects in Oman. The RIl of this factor is 0.568 , which exceeds 0.5 and thus indicates that it is as important as the remaining factors.

\begin{tabular}{|c|c|c|}
\hline Category & Factors & RII \\
\hline \multirow{3}{*}{ Time } & Delay in approving the design drawings & 0.682 \\
\hline & Delay in approving materials & 0.664 \\
\hline & Overall & 0.673 \\
\hline \multirow{2}{*}{ Finance } & Financial corruption & 0.600 \\
\hline & Overall & 0.600 \\
\hline \multirow{4}{*}{$\begin{array}{l}\text { Project Designing, } \\
\text { Planning and } \\
\text { scheduling }\end{array}$} & Errors in design and failure to satisfy design objectives & 0.616 \\
\hline & Insufficient data collection and survey prior to design & 0.600 \\
\hline & Misunderstanding of owner requirement and project objectives & 0.568 \\
\hline & Overall & 0.595 \\
\hline \multirow{2}{*}{ Quality } & Unqualified/ inadequate experienced team & 0.730 \\
\hline & Overall & 0.730 \\
\hline \multirow{4}{*}{$\begin{array}{l}\text { Project Progress and } \\
\text { Development }\end{array}$} & Inadequate project management assistance & 0.660 \\
\hline & Poor communication and coordination with other project parties & 0.616 \\
\hline & Poor supervision of consultant to contractor activities & 0.610 \\
\hline & Overall & 0.629 \\
\hline \multicolumn{2}{|r|}{ Consultant Related Factors-Overall } & 0.635 \\
\hline
\end{tabular}

\section{Contractor-Related Factors affecting the Success of Construction Projects in Oman}

Similar to consultant-related factors, Table 6 shows that quality, time and finance factors are the most important categories related to the contractor's role in construction project success.

The respondents of the current survey agree that the quality and experience of the contractor team and labour are the most important factors related to the contractor's role in ensuring the success of the construction project. This result is consistent with the findings obtained in previous studies (Yong \& Mustaffa, 2012; Muhwezi et al., 2014; Homthong \& Moungnoi, 2016; Tayeh et al., 2018). Unqualified/inadequately experienced labour, unqualified subcontractors and unqualified suppliers are identified as the key factors related to contractors with Rlls of $0.73,0.708$ and 0.692 , respectively, Tayeh et al., 2018 stated that the contractor's financial situation and inability to perform the work affect the project progress negatively and thus lead to project failure. This finding is nearly similar to the current results, where the contractor's unstable financial situation with an RII of 0.682 is the fourth highest contractor-related factor. Contrary to the findings of Muhwezi et al. (2014), the current results show that several contractor-related factors slightly influence the success of construction projects in Oman; these factors include incompetent project manager with an RII of 0.572 , administrative corruption, indiscipline and dishonesty with an RII of 0.546 and frequent equipment breakdowns with an RII of 0.524 . 
Table 6

Rlls of ContractorRelated Factors

\begin{tabular}{|c|c|c|}
\hline Category & Factors & RII \\
\hline \multirow{4}{*}{ Time } & Shortage and delay in material supply & 0.664 \\
\hline & Unrealistic project timelines & 0.648 \\
\hline & Project manager delay in making and issuing decisions & 0.610 \\
\hline & Overall & 0.641 \\
\hline \multirow{4}{*}{ Finance } & Contractor's unstable financial situation & 0.682 \\
\hline & Financial corruption & 0.600 \\
\hline & Poor cash flow (irregular cash flow) & 0.590 \\
\hline & Overall & 0.624 \\
\hline \multirow{2}{*}{$\begin{array}{l}\text { Project Designing, } \\
\text { Planning and Scheduling }\end{array}$} & Ineffective project planning and schedule & 0.584 \\
\hline & Overall & 0.584 \\
\hline \multirow{6}{*}{ Quality } & Unqualified/ inadequate experienced labor and team & 0.730 \\
\hline & Unqualified sub-contractors & 0.708 \\
\hline & Unqualified suppliers & 0.692 \\
\hline & Poor quality of materials & 0.638 \\
\hline & Incompetent project manager & 0.572 \\
\hline & Overall & 0.668 \\
\hline \multirow{9}{*}{$\begin{array}{l}\text { Project Progress and } \\
\text { Development }\end{array}$} & Poor site management and supervision by a project manager & 0.632 \\
\hline & Lack of material & 0.622 \\
\hline & Shortage of labor and equipment & 0.616 \\
\hline & Poor communication and coordination with other project parties & 0.616 \\
\hline & $\begin{array}{l}\text { Poor risk management and inappropriate handling of unexpected } \\
\text { problems and crises }\end{array}$ & 0.610 \\
\hline & Inadequate implementation of health and safety procedures & 0.590 \\
\hline & Administrative corruption, indiscipline, and dishonesty & 0.546 \\
\hline & Frequent equipment breakdowns & 0.524 \\
\hline & Overall & 0.595 \\
\hline \multicolumn{2}{|r|}{ Contractor Related Factors-Overall } & 0.624 \\
\hline
\end{tabular}

\section{External Factors}

The current study states that the delay of government authorities in issuing approvals with an RII of 0.702 is the key external affecting factor of the success of construction projects in Oman.

The Financial Stability Report of Oman indicated that the inflation rate increased from $0.1 \%$ in 2015 to $2.8 \%$ in March 2017, and the rate is expected to increase to an average of $4.1 \%$ in 2017 and stabilise at approximately 3\% in 2020 (Central Bank of Oman, 2017). This increase in the inflation rate significantly affects the construction sector in Oman, as confirmed by the current study. Table 7 shows that the respondents of the survey agree that inflation rate, increase in material prices and labour and transportation costs greatly affect the success of construction projects in Oman with an RII of 0.638 which is matching the finding of Abdul-Rahman et al. (2009). The severe weather condition, which is a physical factor with an RII of 0.556 , is the least external affecting factor of the success of construction projects in Oman. This finding is consistent with that of Yong \& Mustaffa 
(2012), who reported that the weather condition factor is the least significant amongst 15 critical factors affecting the success of construction projects in Malaysia.

\begin{tabular}{|c|c|c|}
\hline Category & Factors & RII \\
\hline \multirow{2}{*}{ Time } & Delay in issuing approvals by authorities & 0.702 \\
\hline & Overall & 0.702 \\
\hline \multirow{3}{*}{ Finance } & Inflation (material prices, labor, and transportation costs) & 0.638 \\
\hline & Poor economic conditions & 0.590 \\
\hline & Overall & 0.614 \\
\hline \multirow{2}{*}{ Environmental } & Emergence of natural factors, such as rainstorms, windstorms, and floods & 0.556 \\
\hline & Overall & 0.556 \\
\hline \multicolumn{2}{|r|}{ External Related Factors- Overall } & 0.622 \\
\hline
\end{tabular}

Based on the above-mentioned discussions and the opinions of the respondents, the following conclusions can be drawn based

1. Factors related to quality rank the most important amongst the investigated factors that affect the success of construction projects in Oman

2. Factors related to clients are the most important, followed, in sequence, by those related to consultant, contractor and external environment.

3. The most important factor affecting the success of projects in Oman are the selection of the lowest bid, and the quality and experience of the project team.

4. The least important factors affecting the success of construction projects in Oman are the contractors' administrative corruption, indiscipline and dishonesty and the frequent equipment breakdowns.

To improve the construction industry in Oman, the following actions are recommended by the authors:

1. A non-profit independent organisation should be established to conduct workshops for sharing best practices and strengthening public awareness on the impact of construction on the national economy.

2. The government should force the construction companies to improve both procurement strategies and approaches to project delivery.

3. The government should facilitate the foreign direct investment by simplifying procedures and providing a smooth investment environment.

Recommendation for Future Studies

1. Further studies that target the construction professionals working in cities other than Muscat should be conducted to increase the sample size and maximise the accuracy of the current results.

2. Future studies on the government's responsibilities in ensuring the success of construction projects should be performed.

\section{Conflict of Interest}

The authors declare that they have no conflict of interest.

\section{Acknowledgements}

Declared none.
Table 7

RIls of External Factors
Conclusions and Recommendations 
Abdul-Rahman, H., Takim, R., \& Min, W. J. (2009). Financial-related causes contributing to project delays, Journal of Retail \& Leisure Property, 8 (3), 225238. https://doi.org/10.1057/rlp.2009.11

Abdul-Rahman, H., Wang, C., Takim, R., \& Wong, S. (2011). Project schedule influenced by financial issues: Evidence in construction industry, Scientific Research and Essays, 6 (1), 205-212. DOI: 10.5897/ SRE10.989

Abu Aisheh, Y. I., Tayeh, B. A., Alaloul, W. S., \& Jouda, A. F. (2021). Barriers of occupational safety implementation in infrastructure projects: Gaza Strip case. International journal of environmental research and public health, 18(7), 3553. https://doi.org/10.3390/ ijerph18073553

Akanni, P.O., Oke, A.E., \& Akpomiemie O.A. (2015). Impact of environmental factors on building project performance in Delta State, Nigeria, HBRC Journal, 11(1), 91-97. https://doi.org/10.1016/j.hbrcj.2014.02.010

Albhaisi, M. A. (2016). Factors causing variation orders in construction projects in gaza strip (Case Study: Qatar Projects), International Journal of Engineering and Management Research. 6(5).

Al Adawi, O. S., Al Hina, S. S., Yahia, H. A. M. and Manchiryal, R. K. (2020). Governmental Stakeholders Impact on Construction Projects in Oman , Journal of Student Research. Houston, U.S. https://doi. org/10.47611/jsr.vi.947

Al Ashmori Y. Y., Othman I. , Rahmawati Y., Mugahed Amran Y.H., Abo Sabah S.H. , Rafindadi A. D., Mikic M. (2020) BIM benefits and its influence on the BIM implementation in Malaysia. Ain Shams Engineering Journal, 11,10131019. https://doi.org/10.1016/j.asej.2020.02.002

Al Harty, A. (2005), Variation orders in construction project in Oman: problems \& remedies. Retrieved from https://www.squ.edu.om/Portals/22/project/CAE/CAE-2005-05-Eng.pdf.

AlMaktoumi, I.S., Khan, F.R., AlMaktoumi, A.R. (2020). Assessing the Factors causing Project Completion Delays in the Construction Sector of Oman using SEM-PLS. Humanities \& Social Sciences Reviews, 8(3), 900-912. Doi.org/10.18510/hssr.2020.8394 https://doi.org/10.18510/hssr.2020.8394

Al-Tmeemy, S. A. H., \& Harun, Z. (2011). Future criteria for success of building projects in Malaysia, International Journal of Project Management, 29(3), 337-348. https://doi.org/10.1016/j.ijproman.2010.03.003

Alzahrani, J.I., \& Emsley, M. W. (2013). The impact of contractors' attributes on construction project success: A post construction evaluation, International Journal of Project Management, 31(2), 313-322. https://doi.org/10.1016/j.ijproman.2012.06.006
Babu, S., \& Sudhakar, B. (2015). Critical Success Factors Influencing Performance of Construction Projects, International Journal of Innovative Research in Science, Engineering and Technology, 4(5), 3285-3292. https://doi.org/10.15680/IJIRSET.2015.0405048

Babu, N. J. (2015). Factors Affecting Success of Construction Project, IOSR Journal of Mechanical and Civil Engineering, 12 (2V), 17-26. DOI: 10.9790/168412251726

Belassi, W, \& Tukel, O.I. (1996). A new framework for determining critical success/failure factors in projects, International Journal of Project Management, 14(3), 141-151. https://doi.org/10.1016/02637863(95)00064-X

Building and Construction Authority Singapore. (2013). Oman country report MAR 2013. Retrieved June 5, 2017, from

https://www.bca.gov.sg/ExportServices/others/ OmanCountryReport.pdf

Central Bank of Oman. (2017). Financial Stability Report-Issue 5. Retrieved from https://cbo.gov.om/ sites/assets/Documents/English/Publications/ FSR/FinacialStabilityReport2017.pdf

Chan, A.P.C., Scott, D. \& Chan, A.P.L. (2004). Factors affecting the success of a construction project, Journal of Construction Engineering and Management, 130 (1), 153-155. https://doi.org/10.1061/ (ASCE)0733-9364(2004)130:1(153)

Chen B. \& Hall N. G. (2021). Incentive schemes for resolving Parkinson's Law in project management, European Journal of Operational Research, 288 (2), pp. 666-681. https://doi.org/10.1016/j.ejor.2020.06.006

Darwish A. M., Tantawy M. M., Elbeltagi E. (2020) Critical Success Factors for BIM Implementation in Construction Projects, Saudi Journal of Civil Engineering, 4(9): 180 191. https://doi.org/10.36348/sjce.2020.v04i09.006

Das, D., \& Ngacho, C. (2017). Critical success factors influencing the performance of development projects: An empirical study of Constituency Development Fund projects in Kenya, IIMB Management Review, 29(4), 276-293. https://doi.org/10.1016/j.iimb.2017.11.005

El-Hallaq, K., \& Tayeh, B. A. (2016). Strategic planning in construction companies in Gaza strip. Journal of Engineering Research and Technology, 2(2).

Evans, A.W. (2004). Economics and Land Use Planning, 1st edition, New Jersey, Wiley-Blackwell. https://doi.org/10.1002/9780470690895

Fellows, R., \& liu, A. (1997). Research Methods for Construction. Oxford, Blackwell Science Ltd.

Fong, P. \& Choi, S. (2000). Final contractor selection using the analytical hierarchy process, Construction Management and Economics, 18 (5), 547-557. https://doi.org/10.1080/014461900407356 
Gerges, M., Austin, S., Mayouf, M., Ahiakwo, O., Jaeger, M., Saad, A., El Gohary, T., (2017). An investigation into the implementation of Building Information Modeling in the Middle East. Journal of Information Technology in Construction (ITcon), Vol. 22, pg. 1-15, http://www.itcon.org/2017/1.

Gillanders, R. (2014) Corruption and infrastructure at the country and regional level, The Journal of Development Studies, 50 (6), 803-819. https://doi.org/ 10.1080/00220388.2013.858126

Global Data. (2017). Construction in Oman - key trends and opportunities to 2021. Retrieved October 5, 2017, from https://www.globaldata.com/store/ report/gd-cn0276mr--construction-in-oman-keytrends-and-opportunities-to-2021/

Global Data. (2018). Construction in Oman - key trends and opportunities to 2022. Retrieved June 5, 2018, from https://www.globaldata.com/store/ report/gd-cn0393mr--construction-in-oman-keytrends-and-opportunities-to-2022/

Homthong, S., \& Moungnoi, W. (2016). Critical success factors influencing construction project performance for different objectives: operation and maintenance phase, Proceedings of 35 th ISERD International Conference, Singapore, 2 April 2016. Retrieved from http://www.worldresearchlibrary. org/up_proc/pdf/256-14612131117-18.pdf

Khosravi, S. \& Afshari, H. (2011). 'A success measurement model for construction projects', International Conference on Financial Management and Economics: ICFME 2011. Hong Kong, 2-3, July. IPEDR Vol.11 (2011) IACSIT Press, Singapore.

Kylindri, S., Blanas G., Henriksen L., \& Stoyan, T. (2012). Measuring project outcomes: A review of success effectiveness variables, MIBES International Conference 2012. Larissa, Greece, 25-27 May 2012. Retrieved from http://mibes.teilar.gr/proceedings/2012/oral/Kylindri-Blana-Henriksen-Tanev.pdf

Lim, C., \& Mohamed, M. (1999). Criteria of project success: an exploratory re-examination, International Journal of Project Management, 17(4), 48-243. https://doi.org/10.1016/S0263-7863(98)00040-4

Mahfuth, K., Loulizi, A., Al Hallaq, K., \& Tayeh, B. A. (2019). Implementation phase safety system for minimising construction project waste. Buildings, 9(1), 25. https://doi.org/10.3390/buildings9010025

Maliha, M. N., Abu Aisheh, Y. I., Tayeh, B. A., \& Almalki, A. (2021). Safety Barriers Identification, Classification, and Ways to Improve Safety Performance in the Architecture, Engineering, and Construction (AEC) Industry: Review Study. Sustainability, 13(6), 3316. https://doi.org/10.3390/su13063316

Malik, S., Taqi, M., Martins, J.M., Mata, M.N., Pereira, J.M., Abreu, A. (2021). Exploring the Relation- ship between Communication and Success of Construction Projects: The Mediating Role of Conflict. Sustainability, 13, 4513. https://doi.org/10.3390/ su13084513

Meland, Q. H., Robertsen, K., \& Hannas, G. (2011), Selection criteria and tender evaluation: the equivalent price model (ETPM), Management and Innovation for a sustainable Built Environment. Amsterdam, The Netherlands. 20 - 23 June 2011. Retrieved from http://resolver.tudelft.nl/uuid:1824f03d-619149c6-9e60-458a056f3eeb

Mordor Intelligence. (2017). Research Report: Construction sector in Oman: analysis of commercial, industrial, infrastructure, institutional and residential construction along with trends (2016 - 2021). Retrieved June 5, 2018, from https://www.mordorintelligence.com/industry-reports/construction-sector-in-oman-industry

Muhwezi, L., Acai, J., \& Otim, G. (2014). An assessment of the factors causing delays on building construction projects in Uganda, International Journal of Construction Engineering and Management, 3 (1), 13-23. DOI:10.5923/j.ijcem.20140301.02

Nguye, T.A., Chovichien, V. (2013). A Practical list of criteria for evaluating construction project success in developing countries, ASEAN Engineering Journal Part C, 3 (2), 21-41.

Oyegoke, A. S., \& Al Kiyumi, N. (2017). The causes, impacts and mitigations of delay in megaprojects in the Sultanate of Oman. Journal of Financial Management of Property and Construction, 22(3), 286302. https://doi.org/10.1108/JFMPC-11-2016-0052 Oyewobi, L., Jimoh, R., Ganiyu, B. \& Shittu, A. (2016). Analysis of causes and impact of variation order on educational building projects, Journal of Facilities Management, 14 (2), 139-164. https://doi. org/10.1108/JFM-01-2015-0001

Parfitt, M. K., \& Sanvido, V. E. (1993). Checklist of critical success factors for building projects. Journal of Management in Engineering, 9 (3), 243-249. https:// doi.org/10.1061/(ASCE)9742-597X(1993)9:3(243)

Ramlee, N., Tammy, N.J., Raja Mohd Noor, R.N.H., Ainun Musir, A., Abdul Karim, N., Chan, H.B., \& Mohd Nasir, S.R. (2016). Critical success factors for construction project, AIP Conference Proceedings, 1774(1), 030011. https://doi.org/10.1063/1.4965067

Raphael, G. (2016). An assessment of critical factors affecting quality performance of government financed construction projects: evidence from Tanzania, Business Management and Strategy, 7 (2), 82-101. https://doi.org/10.5296/bms.v7i2.10014

Ratcliffe, J. \& Stubbs, M. (2003). Urban Planning and Real Estate Development, London and New York: 
Routledge. https://doi.org/10.4324/9780203214633

Tanzi, V., \& Davoodi, H. (1998) Corruption, public investment, and growth. In: Shibata H., Ihori T. (eds) The Welfare State, Public Investment, and Growth. Springer, Tokyo. https://doi.org/10.1007/978-4-431-67939-4_4

Tayeh, B.A., Al Hallaq, K., Alaloul, W. S. \& Kuhail, A. R. (2018). Factors affecting the success of construction projects in Gaza strip, The Open Civil Engineering Journal, 12(1), 301-315. https://doi. org/10.2174/1874149501812010301

Tayeh, B. A., Al Hallaq, K., Al Faqawi, A. H., Alaloul, W. S., \& Kim, S. Y. (2018). Success factors and barriers of last planner system implementation in the gaza strip construction industry. The Open Construction \& Building Technology Journal, 12(1).https://doi. org/10.2174/1874836801812010389

Tayeh, B. A., Al-Hallaq, K., \& Sabha, F. A. (2016). Effects of faulty design phase on school buildings maintenance in Gaza Strip. American Journal of Civil Engineering and Architecture, 4(6).

Tayeh, B. A., Al-Hallaq, K., Yusuf, M. O., \& Sabha, F. A. (2017). Effects of construction phase errors on maintenance of school buildings in Gaza Strip. International Journal of Management, Information Technology and Engineering (BEST: IJMITE), 5(01).

Tayeh, B. A., Durdyev, S., Abuzuhri, I. O., Hosseini, M. R., \& Thurnell, D. (2019). Contractors' attitudes towards the factors affecting sustainability performance: Evidence from Palestine. Business Strategy \& Development, 2(3), 173-179. https://doi. org/10.1002/bsd2.51

Tayeh, B. A., Maqsoom, A., Aisheh, Y. I. A., Almanassra, M., Salahuddin, H., \& Qureshi, M. I. (2020b). Factors affecting defects occurrence in the construction stage of residential buildings in Gaza Strip. SN Applied Sciences, 2(2), 1-12. https://doi.org/10.1007/ s42452-020-1959-1

Tayeh, B. A., Salem, T. J., Abu Aisheh, Y. I., \& Alaloul, W. S. (2020c). Risk Factors Affecting the Performance of Construction Projects in Gaza Strip. The Open Civil Engineering Journal, 14(1). https://doi. org/10.2174/1874149502014010094

Tayeh, B. A., Yaghi, R. O., \& Abu Aisheh, Y. I. (2020a). Project manager interventions in occupational health and safety during the pre-construction phase in the Gaza Strip. The Open Civil Engineering Journal, 14(1). https://doi.org/10.2174/1874149502014010020

Tsado, T. Y., \& Theophilus Y. T. (2014). Equipment maintenance: an effective aspect of enhancing construction project profitability, International Journal of Engineering Science Invention, 3(4), 34-41. Retrieved from http://www.ijesi.org/papers/Vol(3)4/ Version-1/H0341034041.pdf

Umar, T. (2021). Challenges of BIM Implementation in GCC Construction Industry. Engineering, Construction and Architectural Management", Vol. ahead-of-print No. ahead-of-print. https://doi. org/10.1108/ECAM-11-2019-0608

Wang, X., \& Huang, J. (2006). The relationships between key stakeholders' project performance and project success: perceptions of Chinese construction supervising engineers, International Journal of Project Management, 24(3), 253-260. https://doi. org/10.1016/j.ijproman.2005.11.006

Yong, Y. C., \& Mustaffa, N.E. (2012). Analysis of factors critical to construction project success in Malaysia, Engineering, Construction and Architectural Management, 19 (5), 543-556. https://doi. org/10.1108/09699981211259612

\section{About the Authors}

\section{RAMI HAMAD}

Assistant Professor

International College of

Engineering and Management

\section{Main research area}

Construction Management

Structural Engineering

Concrete Technology

\section{Address}

P.O. Box 2511, C.P.O Seeb, P.C. 111, Oman

Tel.: 0096871938475

E-mail: rami@icem.edu.om
BASSAM A. TAYEH

Associate Professor

Islamic University of Gaza

Main research area

Construction Management

Structural Engineering

Concrete Technology

Address

P.O. Box 108, Gaza Strip,

Palestine,

E-mail: btayeh@iugaza.edu.ps
HAMDAN A. AL AISRI

HSE Advisor

Arabian Industry Projects

\section{Main research area}

Construction Management

\section{Address}

P.O. Box 2511, C.P.O Seeb, P.C. 111 , Oman

E-mail: hamdanalesry@gmail.com 